\section{Discussion}

At least 100 cases of thrombocytopenic purpura following rubella have been reported (Pitten, 1929; Ackroyd, 1949; Steen and Torp, 1956; Tadžer, 1958; Cohen et al., 1960; Ferguson, 1960; Sladden, 1963; S. J. Wallace, 1963; Plotkin, 1964; D. C. Wallace, 1964; Adkins and Fernbach, 1965; Bayer et al., 1965; Lokietz and Reynolds, 1965; Svenningsen, 1965; Morse et al., 1966; Sander, 1966; Staub, 1968; Volpato et al., 1969), though laboratory confirmation of diagnosis is available in only four instances (Plotkin, 1964; Volpato et al., 1969). The finding by Myllylä et al. (1969) of higher levels of platelet aggregating antibody in seven patients with this abnormality compared with a control group of patients with uncomplicated rubella suggests that this may wholly or partly result from an immunological mechanism. Most of the information regarding the carpal-tunnel syndrome complicating rubella is from clinical notes and the pathogenesis is not discussed (Bailey, 1962; Courtenay, 1962; Heathfield, 1962; Brodribb, 1963; Chambers and Bywaters, 1963). The work of Lee et al. (1960), though inconclusive, suggests that in rubella arthritis there is an alteration of the euglobulin fraction of serum in some cases.

By showing a prolonged rubella-specific IgM response in three cases of rubella with complications our results suggest that persistence of infection or alteration of the immunological response may be factors in pathogenesis. The virus infection may have continued or, if absent, may at some stage have extrinsically stimulated the antibody-forming cells to produce this particular response. When infection occurs early in pregnancy the virus has the predilection for differentiating immunocompetent cells in the embryo; our findings may be evidence that a similar differentiation may occur in some cases in the mature individual with resulting clinical complications.

This work is supported by a grant from the National Fund for Research into Crippling Diseases. We wish to thank Dr. C. M. B. Field and Dr. E. White, the physicians in charge of the patients; Dr. C. C. Kennedy and Dr. J. E. P. Fitzpatrick, the haematologists who investigated the patients with thrombocytopenic purpura; Mr. D. W. Neill, the biochemist who checked the purity and specificity of the antiglobulin preparations; and Miss Ann J.
Fulton and Mr. John Russell for technical assistance. Professor K. B. Fraser gave continued encouragement and advice throughout the study.

\section{REFERENCES}

Ackroyd, J. F. (1949). Quarterly fournal of Medicine, 18, 299.

Adkins, A. T., and Fernbach, D. J. (1965). Foumal of the American Medical Association, 193, 243.

Bailey, G. (1962). British Medical fournal, 1, 1207.

Baublis, J. V., and Brown, G. C. (1968). Proceedings of the Society for Experimental Biology and Medicine, 128, 206.

Bayer, W. L., Sherman, F. E., Michaels, R. H., Szeto, I. L. F., and Lewis, J.'H. (1965). New England fournal of Medicine, 273, 1362.

Brodribb, H. S. (1963). British fournal of Clinical Practice, 17, 726.

Chambers, R. J., and Bywaters, E. G. L. (1963) Annals of the Rheumatic Diseases, 22, 263.

Cohen, H. J., et al. (1960). Archives of Pediatrics, 77, 138.

Cohen, S. M., Ducharme, C. P., Carpenter, C. A., and Deibel, R. (1968). Fournal of Laboratory and Clinical Medicine, 72, 760.

Courtenay, M. J. F. (1962). British Medical fournal, 1, 1698.

Ferguson, A. W. (1960). Pediatrics, 25, 400.

Gispen, R., and Brand-Saathof, B. (1967). Archiv für die gesamte Virusforschung, 21, 334.

Heathfield, K. W. G. (1962). British Medical fournal, 2, 58.

Lee, P. R., Barnett, A. F., Scholer, J. F., Bryner, S., and Clark, W. H. (1960). California Medicine, 93, 125.

Lokietz, H., and Reynolds, F. A. (1965). Fournal-Lancet, 85, 226.

Morse, E. E., Zinkham, W. H., and Jackson, D. P. (1966) Archives of Internal Medicine, 117, 573.

Myllylä, G., Vaheri, A. Vesikari, T., and Penttinen, K. (1969). Clinical and Experimental Immunology, 4, 323.

Pitten, T. (1929). Archiv für Kinderheilkunde, 86, 114.

Plotkin, S. A. (1964). Fournal of the American Medical Association, 190, 265.

Rinderknecht, H. (1962). Nature, 193, 167.

Sander, C. H. (1966). Michigan Medicine, 65, 1076.

Schmidt, N. J., Lennette, E. H., Woodie, J. D., and Ho, H. H. (1966) fournal of Laboratory and Clinical Medicine, 68, 502.

Sladden, R. A. (1963). British Medical fournal, 2, 1587.

Staub, H. P. (1968). Clinical Pediatrics, 7, 350.

Steen, E., and Torp, K. H. (1956). Archives of Disease in Childhood, 31, 470 .

Svenningsen, N. W. (1965). Acta paediatrica Scandinavica, 54, 97.

Tadžer, I. S. (1958). Acta medica Iugoslavica, 12, 233.

Volpato, S., Vigi, V., and Gaburro, D. (1969). Lancet, 2, 1249.

Wallace, D. C. (1964). Medical fournal of Australia, 2, 97.

Wallace, S. J. (1963). Lancet, 1, 139.

\title{
Measurement of Recovery from Outpatient General Anaesthesia with a Simple Ocular Test*
}

\author{
J. G. HANNINGTON-KIFF, $†$ M.B., B.SC., F.F.A. R.C.S.
}

\begin{abstract}
Cummary: Measurements of extraocular muscle balance with a Maddox wing can be a useful clinical test of the rate of recovery from general anaesthesia. In 65 dental outpatients recovery was found to be most rapid in those patients given only nitrous oxide, oxygen, and halothane, whereas the previous administration of methohexitone, propanidid, or thiopentone for induction was associated with slower recovery. Recovery rates after
\end{abstract}

*Presented at a seminar on Outpatient Surgery held by the South West Metropolitan Regional Hospital Board at Kingston Hospital in October 1969.

tConsultant Anaesthetist, Department of Anaesthetics, Farnham Group of Hospitals. methohexitone and propanidid were similar and rapid enough to confirm their choice for intravenous induction of anaesthesia in outpatients, but delayed recovery after thiopentone showed that this agent is best avoided in these circumstances.

\section{Introduction}

When new plans for the deployment of medical resources in the community come into effect probably more patients will receive general anaesthesia for diagnostic and minor surgical procedures as outpatients, and in this area one of the new "best-buy" hospitals is being built which will include a special department for day surgery (Harrington and Goodman, 1969). 
Accordingly, it would be most useful to have a simple quantitative test to supplement the clinical assessment of recovery from general anaesthesia. The results are presented of initial studies which show that measurement of the balance of the extraocular muscles with a Maddox wing can be a sensitive indication of the rate of recovery from general anaesthesia and, furthermore, can be used to compare recovery rates after different anaesthetic techniques.

\section{Principle of the Ocular Test}

The physiological position of rest of the eyes is in divergence with a slight upward displacement and the maintenance of normal single vision is an active process, largely depending on the degree of tone in the medial recti, so that reduction in the general muscle tone, for instance after general anaesthesia, will cause divergence of the eyes. Such divergence can be measured in the conscious co-operative patient with the Maddox wing, in which the relative position of the eyes is directly measured in prism dioptres. The Maddox wing can also measure relative vertical and rotatory movements of the eyes, but these are less common after general anaesthesia, and only the horizontal scale is shown in the modified Maddox wing used in this study (Fig. 1). Change in accommodative power

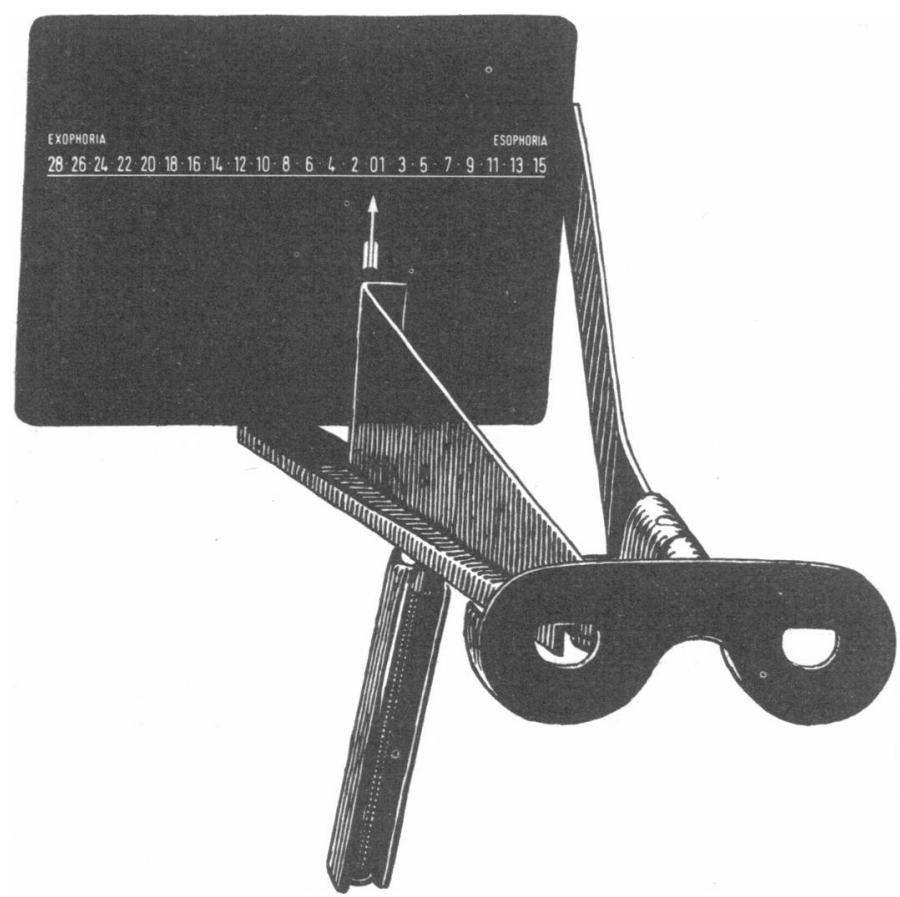
Fig. 1.- Modified Maddox wing. Exophoria and esophoria-ten-
dency of eyes to diverge and converge respectively. (This figure is dency of eyes to diverge and converge respectively. (This figure is
reproduced by kind permission of the Editors of the Proceedings of the reproduced by kind permission of the Editors of
Royal Society of Medicine.)

following general anaesthesia can affect the Maddox wing readings, but further studies suggest that the principal effect is due to change in the tone of the extraocular muscles (Hannington-Kiff, 1970).

The use of the Maddox wing is on the whole easily understood by the patient. When the subject looks into the instrument his field of vision is so divided by oblique and vertical wings that an arrow is seen by the right eye and a numbered scale by the left eye. Divergence of the eyes causes the image of the arrow apparently to move along the scale, and the subject is asked to report what number the image of the arrow points to when it has ceased moving. The patient must be instructed to relax, as voluntary movement of the eyes can affect the results.

\section{Patients and Methods}

Unpremedicated outpatients attending for dental extractions were chosen for this investigation as they present in relatively large numbers and have short uniform types of operation which require simple light general anaesthesia followed by rapid recovery. During the course of this study all patients who attended my dental sessions were included, and of 80 such cases 65 were able to give Maddox wing readings without difficulty before anaesthesia. Of the 15 cases excluded, two had a limited command of English, two were mentally subnormal, one had only unilateral vision, and 10 were too young to understand how to use the Maddox wing (however, two intelligent children aged 6 years, who were able to give readings, were included in the study).

Each patient was weighed on admission and a control Maddox wing reading was taken after an explanation of the use of the instrument. Four anaesthetic techniques were compared by using each in rotation at consecutive sessions, as this was more convenient than giving consecutive patients different techniques. In three techniques anaesthesia was induced by the intravenous injection, in a single dose, of $1 \%$ methohexitone $1.2 \mathrm{mg} . / \mathrm{kg}$., $2.5 \%$ propanidid $4.0 \mathrm{mg} . / \mathrm{kg}$., or $2.5 \%$ thiopentone $3.6 \mathrm{mg} . / \mathrm{kg}$., and maintained with a $2: 1$ mixture of nitrous oxide and oxygen. In about a third of the patients in each of these three groups, however, halothane had to be added in $0.5-1.0 \%$ concentration for a short period when these patients began to move during the operation. In the fourth technique patients were given an entirely inhalational anaesthetic which consisted of a $2: 1$ mixture of nitrous oxide and oxygen with the addition of halothane $1-2 \%$.

The doses of methohexitone, propanidid, and thiopentone were chosen in the light of clinical experience and the relationships between them are about the same as those reported by Clarke et al. (1968). It is emphasized that all of these patients were anaesthetized by a clinical routine and no attempt was made to limit their management by pharmacological considerations. All patients were anaesthetized in the dental chair and gases were delivered to a nasal mask from a machine of the Boyle pattern, with a Fluotec vaporizer for the administration of halothane.

At the completion of the study anaesthesia had been induced with methohexitone in 20 cases, propanidid in 19 cases, thiopentone in 10 cases, and inhalational agents in 16 cases. Recovery was obviously delayed after thiopentone, and this agent was withdrawn from the study after it had been used in 10 cases. Two patients who attended sessions where it was planned to use only inhalational agents asked to be given an intravenous agent, and so each was anaesthetized by the next technique in the rotation. The groups of patients anaesthetized by these four techniques were similar with regard to age and the duration of operation (see Table). For

TABle I.-Age and Sex of Patients Together with Operation Times

\begin{tabular}{|c|c|c|c|c|c|c|}
\hline & & & \multicolumn{4}{|c|}{ No. of Patients } \\
\hline & & & Halothane & Methohexitone & Propanidid & Thiopentone \\
\hline $\begin{array}{l}\text { Age groups : } \\
5-14 \text { years } \\
15-24 \quad " \\
25-34 \quad " \\
35-44 \quad " \\
45-54 \quad " \\
55-64 \quad "\end{array}$ & $\begin{array}{l}. \\
\because \\
\because \\
\because\end{array}$ & $\begin{array}{l}. \\
\because \\
\because \\
\because \\
.\end{array}$ & $\begin{array}{l}5 \\
6 \\
3 \\
1 \\
1 \\
0\end{array}$ & $\begin{array}{l}6 \\
6 \\
3 \\
4 \\
1 \\
0\end{array}$ & $\begin{array}{l}4 \\
7 \\
3 \\
2 \\
1 \\
1 \\
2\end{array}$ & $\begin{array}{l}3 \\
3 \\
2 \\
2 \\
0 \\
0\end{array}$ \\
\hline $\begin{array}{l}\text { Male patients } \\
\text { Female patients }\end{array}$ & $\therefore$ & $\because$ & $\begin{array}{l}9 \\
7\end{array}$ & $\begin{array}{l}10 \\
10\end{array}$ & $\begin{array}{r}9 \\
10\end{array}$ & $\begin{array}{l}5 \\
5\end{array}$ \\
\hline Total & . & . & 16 & 20 & 19 & 10 \\
\hline $\begin{array}{l}\text { Operation times: } \\
3-5 \mathrm{~min} \text {. } \\
6-8 \text { " } \\
9-11 "\end{array}$ & $\begin{array}{l}: \\
\cdots \\
\cdots\end{array}$ & $\begin{array}{l}\ldots \\
\cdots\end{array}$ & $\begin{array}{l}9 \\
5 \\
2\end{array}$ & $\begin{array}{r}14 \\
3 \\
3\end{array}$ & $\begin{array}{r}13 \\
3 \\
3\end{array}$ & $\begin{array}{l}6 \\
3 \\
1\end{array}$ \\
\hline
\end{tabular}


convenience they are referred to as the halothane, methohexitone, propanidid, and thiopentone groups. There was no statistical difference between the preoperative Maddox wing readings in the four groups.

It is most useful to establish recovery trends; therefore readings were taken with the Maddox wing at minute intervals for the first 10 minutes after completion of dental treatment, when changes were most rapid, and thereafter at fiveminute intervals for 20 minutes. Although patients varied in the time at which they could give their first reading, all were able to give a reading within four; minutes postoperatively. Unfortunately, it was not convenient to continue the study beyond 30 minutes in all the patients as this would have upset the routine of these busy dental clinics. Patients who use spectacles were made to wear them whenever their eyes were tested; both before and after general anaesthesia.

\section{Results}

The degree of divergence of the eyes as measured with the Maddox wing was found to correlate well with the clinical recovery of the patients from general anaesthesia. Patients who were obviously drowsy showed divergence of the eyes, which diminished as recovery occurred, and those who were considered to be fully recovered invariably showed little or no such divergence.

The postoperative changes in the Maddox wing readings are shown for a typical case from each of the four groups of patients (Fig. 2). In each instance the initial rate of change was rapid, but whereas the halothane case quickly recovered completely, the intravenous cases each showed a further period of slower recovery. The halothane case, compared with the intravenous cases (Fig. 2), had less initial divergence of the eyes, and this was, in general, the finding for the halothane and intravenous groups as a whole. Since in this dental practice patients are usually expected to be able to leave the chair with assistance within five minutes postoperatively, this time was chosen to compare the readings obtained in each of the groups. On the whole, the divergence of the eyes five minutes postoperatively was less in the halothane group than in each of the intravenous groups, and in each instance the difference is significant at the $1 \%$ level (Fig. 3). Though the results shown in Fig. 3 suggest a trend of increasing delay in recovery from methohexitone, through propanidid to thiopentone, they are not significantly different at this time.

Recovery curves were established for each group by calculating the percentage of patients with abnormal Maddox wing readings (compared with their preoperative values) at each of the selected postoperative intervals (Fig. 4). Patients who were asleep or unco-operative at the initial postoperative testing-times were considered to have abnormal readings because in every case the first reading after awakening showed divergence of the eyes; which gradually diminished as the patient recovered. Points are marked in Fig. 4 only when all the patients in each group could actually give readings, and it may be seen that this was two minutes postoperatively for the halothane group and four minutes postoperatively for each of the intravenous groups. The probit transformation was used to obtain drawing points for the curves, and the necessary calculations were made with the aid of a computer programme (I.B.M. 1620-06.0.059) which had previously been checked on a desk-calculator. This programme was also used to calculate the best estimate of the time from completion of dental extractions to full recovery of the Maddox wing readings in $50 \%$ of the patients in each group, apart from the thiopentone group, where this was beyond the limit of the study: halothane group 4.5 minutes, methohexitone group 12.5 minutes, propanidid group 16.3 minutes.

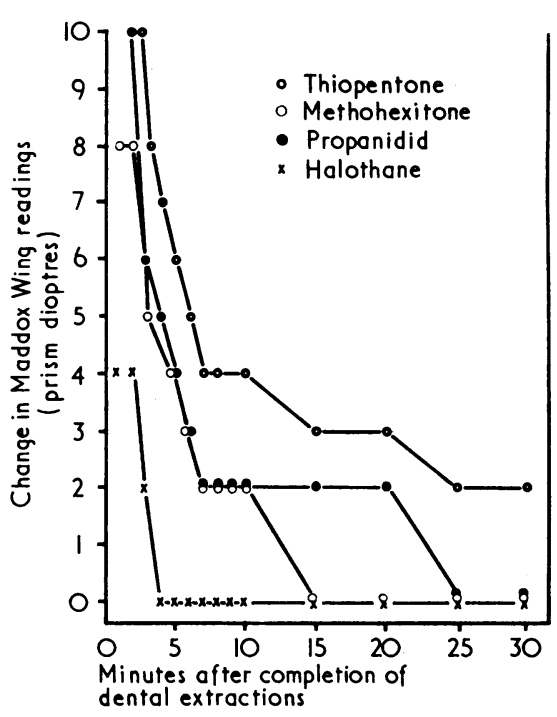

FIG. 2.-Recovery of the Maddox wing readings after completion of dental extractions in a typical case from each of the four groups. The "step" effect during the delayed recovery after intravenous agents is the result of a "rounding-off". error introduced by the subjects who naturally relate the arrow (Fig. 1) to what they consider the nearer of the adjacent numbers an the scale of the Maddox wing.

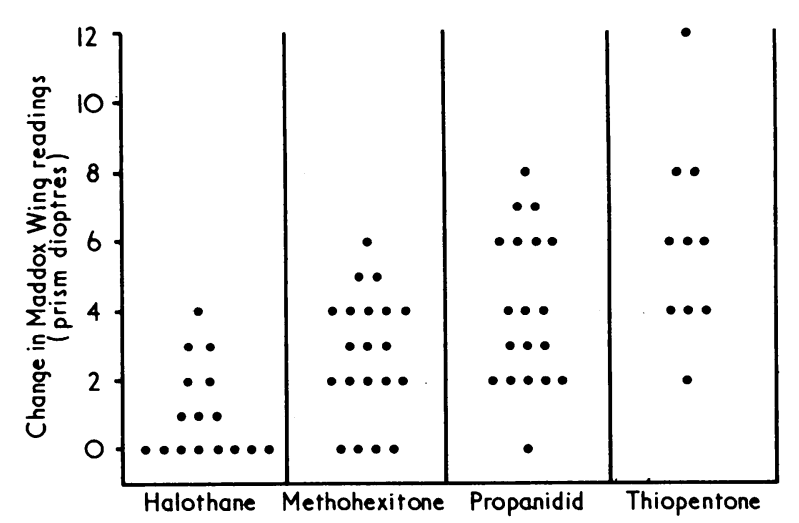

FIG. 3.- Change in the Maddox wing readings five minutes after the completion of dental extractions. Since the results in each of the four groups are not all normally distributed, they were analysed statistically by the Wilcoxon-White ranks test which is non-parametric. The halothane group is significantly different from each of the intravenous groups $(P<0.01)$. The apparent difference between the intravenous groups is not significant.

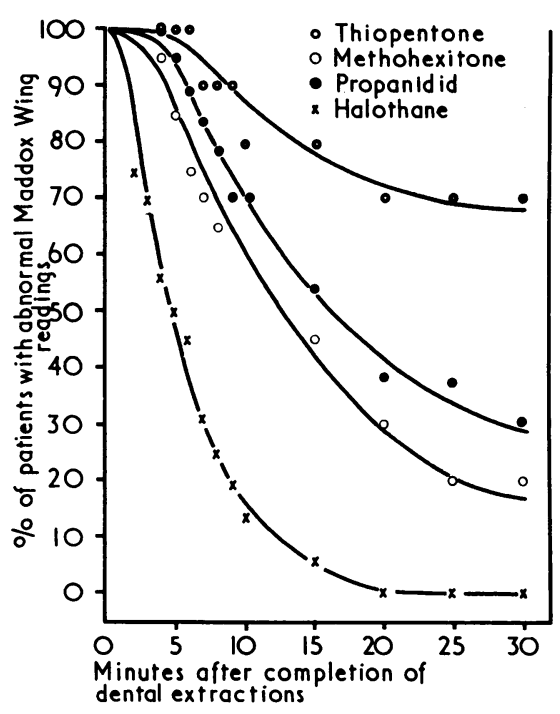

Fig. 4.-Recovery curves which show the percentage of patients with abnormal Maddox wing readings at the set testing-times postoperatively. 
In the propanidid group six out of the 19 patients retched or vomited soon after regaining consciousness, whereas only one (in the halothane group) retched out of all the 46 patients in the other groups. The probability of this happening by chance is only 0.0019 (from Fisher's exact significance test).

\section{Discussion}

The persistence of the effects of intravenous anaesthetic agents in the postoperative period has been one of the principal objections to their use in outpatients, and the results of this study suggest that this reservation can be justified, especially in the case of thiopentone. Though recovery is quickly complete after purely inhalational anaesthesia with nitrous oxide, oxygen, and halothane, undoubtedly most patients, apart from small children, prefer an intravenous injection to the application of a mask for the induction of anaesthesia. Inevitably, therefore, many outpatients will receive intravenous anaesthesia and, furthermore, will very likely leave hospital before they are fully recovered. Fig. 4 shows that 30 minutes postoperatively extraocular imbalance was still present in $20 \%$ of patients after methohexitone, $30 \%$ after propanidid, and $70 \%$ after thiopentone. The imbalance at this time was of course only minor, but it is important that a test of postoperative recovery should be so sensitive that impairment which is otherwise not clinically obvious may be recognized. Work is in progress to develop an ocular test which may conveniently be used generally in clinics to assess recovery in outpatients who require anaesthesia or other medication for operations and diagnostic procedures.

The curves in Fig. 4 probably mainly reflect recovery due to physical redistribution of the anaesthetic agents. The recovery curves after propanidid and methohexitone are similar, and so it is interesting to speculate that recovery in both cases is largely due to redistribution, though propanidid is quite rap- idly metabolized to inactive products (Doenicke et al., 1968) whereas methohexitone is not (Brand et al., 1963). It is hoped to study these two agents for a longer period postoperatively, when metabolic degradation could be the principal factor governing complete recovery. Doenicke and Kugler (1965) reported electroencephalographic evidence of the activity of methohexitone up to 12 hours after its administration whereas there was no such prolonged effect after propanidid.

The high incidence of retching and vomiting in the early postoperative period after propanidid was a nuisance, but seemed to have remarkably little general effect on the patients; and recovery, as judged by the Maddox wing, was not significantly slower in those who vomited. Dundee (1965) also reported a high incidence of nausea and vomiting after propanidid, but this was not the experience of Zindler (1965).

I should like to thank Miss E. H. L. Duncan for her help and advice in the handling of the data.

REFERENCES

Brand, L., Mark, L. C., Snell, M. McM., Vrindten, P., and Dayton, P. G. (1963). Anesthesiology, 24, 331.

Clarke, R. S. J., Dundee, J. W., Barron, D. W., and McArdle, L. (1968). British foumal of Anaesthesia, 40, 593.

Doenicke, A., Krumey, I., Kugler, J., and Klempa, J. (1968) British Fournal of Anaesthesia, 40, 415.

Doenicke, A., and Kugler, J. (1965). Acta Anaesthesiologica Scandinavica, Suppl. No. 17, p. 99.

Dundee, J. W. (1965). Acta Anaesthesiologica Scandinavica, Suppl. No. 17, p. 77.

Hannington-Kiff, J. G. (1970). Proceedings of the Royal Society of Medicine, 63, 73 .

Harrington, A. B., and Goodman, H. (1969). Health Trends, 1, No. 1, p. 2.

Zindler, M. (1965). Acta Anaesthesiologica Scandinavica, Suppl. No. 17, p. 75.

\title{
Bacteriological Studies of the Modified Kiil Dialyser
}

\author{
D. M. JONES,* M.D., M.R.C.PATH., DIP. BACT. ; BARBARA M. TOBIN, $†$ PH.D., DIP. BACT. \\ G. R. HARLOW, $\ddagger$ M.B. ; A. J. RALSTON, $\emptyset$ M.B., M.R.C.P.
}

\begin{abstract}
Summary: Bacterial proliferation in dialysis fluid during haemodialysis may be associated with rigors, hypotension, and bacteraemia. Investigations carried out in a period in which rigors were particularly common showed the source of bacteria to be parts of the gasket system of the Kiil dialyser, areas that are inaccessible to disinfectants.
\end{abstract}

\section{Introduction}

Intermittent haemodialysis is now widely used in managing terminal chronic renal failure. Early in the development of the technique, particularly when recirculating systems were used, bacterial proliferation in the dialysis fluid was found to be common and sometimes associated with rigors, shock, and

\footnotetext{
* Consultant Bacteriologist.

tResearch Assistant.

†Clinical Assistant.

Consultant Physician

Withington Hospital, Manchester 20
}

even bacteraemia (Sherris, Cole, and Scribner, 1961; Curtis, Wing, and Coleman, 1967).

During June, July, and August 1969 an increasing number of severe reactions, consisting of rigors, high fever, and hypotension, occurred among the patients in the Withington Haemodialysis Unit. Nearly all these reactions began about one hour after beginning dialysis, and some were accompanied by bacteraemia due to Enterobacter aerogenes, this same organism being isolated from the blood stream of several patients. These findings led us to conduct a bacteriological study of the Kiil dialyser at various stages of building and, in particular, to examine the bacteriological state of the prepared dialyser just before dialysis.

\section{Method}

We use modified Kiil dialysers (Cole, Quinton, Williams, Murray, and Sherris, 1962), referred to as types A and B, obtained from two of the English manufacturers, the patients receiving three 10-hour dialyses a week. The modified Kiil 